\title{
The dynamics of Pecking Order and Agency theories on crowdfunding concept as alternate finance for start-up businesses.
}

\author{
Francis Kwaku Kuma ${ }^{1}$ and Mohd Effandi Yosuff ${ }^{2}$ \\ ${ }^{1}$ Universiti Teknologi Malaysia, Skudai, Johor Bahru \\ ${ }^{1}$ Department of Accountancy, Koforidua Technical University. \\ Email: francis.kwaku.kuma@graduate.utm.my; Tel: +601162086140 \\ ${ }^{2}$ Universiti Teknologi Malaysia, Skudai, Johor Bahru \\ Email: effandi@utm.my
}

${ }^{1}$ Correspondence: francis.kwaku.kuma@graduate.utm.my

\begin{abstract}
The study explores the relevance of theoretical aspect of crowd financing by reviewing the defining literature on Pecking Order and Agency theories in details and evaluates applications of these theories based on crowdfunding. In particular, the study critically considers the key concepts of these theories and how they could be applied in practical terms. The study decides to adopt Pecking Order and the Agency theories because they provide valuable insights into the trend of crowdfunding streams available to firms. The paper primarily adds to existing literature on the broader definition of crowdfunding as a concept and then examine the relationship between this concept and its practical applications to the chosen theories. The study combines these theoretical perspectives with the practical aspects of startup companies raising finance using the crowd because a broad reading of the literature tends to point to in this direction. The key concepts of these theories are critically considered and the study is conducted in the form of review of literature and expression of opinion.
\end{abstract}

Keywords: Crowdfunding, Start-ups, Agency theory, Pecking order theory.

Citation: author ${ }^{1}$, author ${ }^{2}$, author ${ }^{3}$. The dynamics of Pecking Order and Agency theories on crowdfunding concept as alternate finance for start-up businesses. 2020; 4(1): 1-13.

Received: (February 2, 2020)

Accepted: (March 31, 2020) 


\subsection{Introduction}

\subsection{Background}

The study decides to adopt Pecking Order and Agency theories because they provide valuable insights into the funding streams available to firms and for that matter USOs. Numerous studies have shown that Pecking order theory advances the view that companies will prioritize their sources of financing in terms of the source that will inure to their benefit. Until recently the three most basic sources of finance for companies are internal funds, debt and equity finance, (Moedl 2019). Consequently, in terms of prioritization companies will prefer their own internal funds for their operations rather than external sources. They only opt for external source such as debt and equity finance as a last option when their own funds is exhausted. The pecking order theory therefore constitute a sort of a hierarchy of financing where internal funds is top on the hierarchy followed by debt and at the bottom is equity finance. (Moedl 2019). The Agency theory on the other hand expounds the relationship between business principals and their stakeholders (Agents) who are the resource holders. Under the relationship, the principal(s) hires the agent to perform a service on their behalf. The agent is the decision maker who takes the day-to-day decisions but incur no risk in any form (Hill, C. W., \& Jones 1992). Compared with past researches this study wants to advance the current literature on the use of crowdfunding as an alternate finance for SMEs in Ghana (Cambridge centre for Alternative Finance, 2017; Berndt and Mbassana, 2016; InfoDev, 2015; Afristart, 2016). Currently, there is a limited research on the use of crowdfunding as a startup capital for SMEs in Ghana. The study therefore aims at building on current research on crowdfunding as source for funding for start-up companies (Moon and Hwang, 2018; Walthoff-Borm et al., 2018; Kuppuswamy and Bayus, 2017; Ahlers et al., 2015; Belleflamme et al., 2014)

The question therefore is; are theoretical aspect of crowdfunding financing relevant to the concept of crowdfunding? We therefore categorized the research problem set for this study as follows: First, we explain the pecking order and agency theories and their implications to the study. Secondly, we examine the applications of these theories and how well they hold in the study. Thirdly, we focus on the role of stakeholder relationships on identified crowdfunding platforms in the success of crowdfunding.

\subsection{Methodology}

Existing research suggest that there is a rise in popularity of crowdfunding as alternate funding for start-up businesses and this has caught the interest of stakeholders as well as scholars who have come out with varied definitions (Cumming, Leboeuf, and Schwienbacher 2019; Mollick 2014; Kuppuswamy and Bayus 2013). However, despite growing scholarly interest in the subject scholars are yet to come out with an accepted definition which fully captures the dynamics of this phenomenon (Agrawal et. al., 2014; Ahlers et. al., 2015; Mollick, 2014). Crowdfunding as a concept refers to fund raising activities from a large group of people using online platforms to fund start-up projects (Cumming, Leboeuf, and Schwienbacher 2019; Mollick 2014). This takes the form of an open call Crosetto \& Regner(2018), Maciel et al. (2017) and (Howe 2006)and it is not limited by geographical boundaries(A. Agrawal, Catalini, and Goldfarb 2015; Martínez-Climent, Zorio-Grima, and Ribeiro-Soriano 2018). 


\subsection{Application of theories to crowdfunding concept}

\subsection{Pecking Order Theory}

Numerous studies have shown that Pecking order theory advances the view that companies will prioritize their sources of financing in terms of the source that will inure to their benefit. Until recently the three most basic sources of finance for companies are internal funds, debt and equity finance, (Moedl 2019). Consequently, in terms of prioritization companies will prefer their own internal funds for their operations rather than external sources. They only opt for external source such as debt and equity finance as a last option when their own funds is depleted. The pecking order theory therefore constitute a sort of a hierarchy of financing where internal funds is top on the hierarchy followed by debt and at the bottom is equity finance(Vanacker and Manigart 2010). In a closely related study,Jarallah, Saleh, \& Salim(2019) argue that pecking order theory has some linkage to asymmetric information. This is because managers unlike potential investors have better information about their companies. These information ranges from future prospects of the company to the risky nature of the company as well as the value of the company(Jarallah, Saleh, and Salim 2019). Consequently, asymmetric information determines the choices of the sources of finance. That is whether debt or equity finance. Following from this argument, Bhama, Jain, \& Yadav, (2019)contend that it is cheaper for companies to access debt finance in terms of transaction cost comparatively to equity finance. In addition, when given the opportunity companies will pay back their indebtedness to their lenders rather than ploughing back their shares from shareholders.

The hierarchy of financial needs of firms is shown in Figure 1. As can be seen from the figure, top on the hierarchy is internal funding, which is closely followed by debt and equity. Crowdfunding, which was not part of the original proposition made popular by Myers and Mailuf (1984), has somewhat found its way on the hierarchy. This is because crowdfunding gives entrepreneurs access to capital, which hitherto they will be unable to access from traditional funding sources. There is ample research to suggest that most entrepreneurs fail to raise venture capital because they do not qualify (Landström et al., 2019; Block et al., 2018; Cox and Nguyen, 2018; Bellavitis et al., 2017) . This is because they have growth challenges and lack the potential for a large public offering (Bechter et al. 2011). In addition, there are too many entrepreneurs competing for funding from fewer venture capitalists thereby creating funding gaps (Sigar, 2012). These funding gaps have been filled by crowdfunding, which presents varied funding opportunities for entrepreneurs and small businesses who cannot access funding from the banks (Dorfleitner et al., 2018; Vismara, 2016; Agrawal et al., 2014; Mollick, 2014; Sahm et al., 2014).

Unfortunately, the hierarchy did not recognize other valuable sources of funding such as Susu, Harambee funding system, which existed in Africa(Dieter, 2001; Aryeetey, 2005). These African traditional systems of funding mobilization from the community is use in support of micro enterprises(Vershinina, Woldesenbet Beta, and Murithi 2018). 


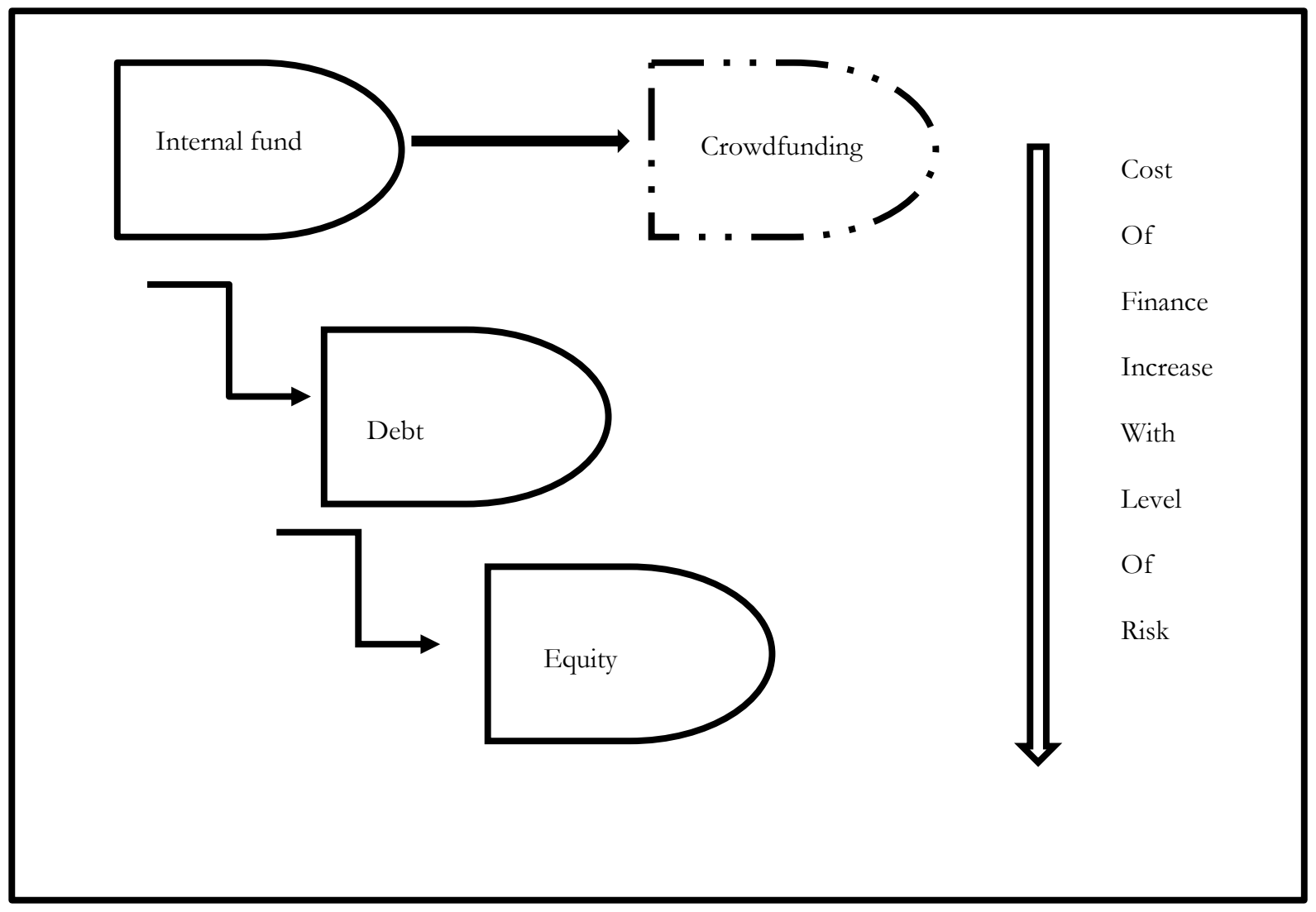

Figure 1 Pecking Order Model - Hierarchical sources of finance for firms

Source: Myers and Mailuf (1984), added on by author

\subsection{Pecking order and crowdfunding}

Much of the literature on Pecking Order theory focuses on the three main hierarchical sources of finance for companies, which are internal source, debt and equity(Walthoff-Borm, Schwienbacher, and Vanacker 2018). However scholars have found backing for the notion that businesses invariable list on crowdfunding platform as a last option after exhausting their internally generated funding as well as debt and equity funding,(Moedl 2019). Drawing from the Pecking Order theory extant research has raise the concerns that due to inadequate internal sources and lack of access to debt and equity funding start-ups are now relying on alternate sources such as crowdfunding(Cosh, Cumming, and Hughes 2009; Bellavitis et al. 2017). Specifically, this is because of the stringent conditions attached to debt and equity finance by banks and other financial institutions.

The above assertion is particularly true for unprofitable firms, which lack internal finance and firms with excessive debt levels with intangible assets(Vanacker and Manigart 2010). In order to address these funding challenges, these firms search for crowdfunding as an alternate funding from a pool of small investors(Hervé and Schwienbacher 
2018). Subsequently, the advent of equity crowdfunding has made it possible for most start-ups to raise funding from small investors (equity crowdfunding)(Kaartemo 2017). They can also raise reward-based crowdfunding directly from prospective consumers without depending on the banks (Bellavitis et al. 2017). Consistent with theoretical arguments, it has been established that crowdfunding allows start-ups to control their businesses comparative to other types of equity finance. In addition equity crowdfunding has contractual terms that are less stringent (Vismara 2018). It must be made clear that although Pecking Order theory was established in the framework of bigger businesses, it is worth nothing that it has some relevance for crowdfunding (Cosh, Cumming, and Hughes 2009).

In terms of cost crowdfunding is cheaper and more efficient comparative to traditional sources of finance such as debt and equity finance (Bellavitis et al. 2017). It is not bound by geographical location so funding can be raised across continents (A. K. Agrawal et al. 2011). With an access to internet, any project initiator can solicit for funding in any part of the world using crowdfunding. It takes the form of a general appeal to the public and any member of the public can participate in the crowdfunding campaign process (Moon and Hwang 2018). These features therefore makes crowdfunding a better alternative for SMEs in Ghana because they struggle to raise funding from the traditional sources and existing micro-finance companies (Aryeetey, E. 2005).

\subsection{Challenges of Pecking order theory}

Firstly, the pecking order theory to some extent has been criticized severally and one of the criticisms by some scholars is that despite its relevance as a viable alternate finance because it is relatively a new financing alternative (Mollick 2014). Therefore, firms will only select it if their internal funds are inadequate. In relation to the pecking order, crowdfunding is still not regard as high on the hierarchy (Walthoff-Borm, Schwienbacher, and Vanacker 2018). Secondly, in a related point of criticism Ahlers et al., (2015) pointed out that pecking order has substantial information asymmetries challenges. This is because backers of crowdfunding projects have limited capacity to execute background checks on the start-ups they are interesting inputting their investment. This therefore increase the risk level of their investments(Estrin, Gozman, and Khavul, 2018).

To sum up, it has been established by scholars that even though debt finance is top on the hierarchy for firms, banks are unwilling to provide loans to most firms(Cosh, Cumming, and Hughes 2009). The banks usually conduct credit checks on the firms before issuing out loans to them. This opinion is strengthened by the fact that banks prefer to give out loans to firms with record of accomplishment, with a quality collateral as well as a steady flow of cash (Vanacker and Manigart, 2010). In the Ghanaian context, crowdfunding could invariably be an alternatively source of funding for the SMEs. Crowdfunding for instance presents unique opportunity for the SMEs to test the marketability of their products (Valanciene and Jegeleviciute, 2013; Bechter et al. 2011). This is because crowdfunding as concept involves the use of large crowd who usually express interest in a business model by supporting it financially. Accordingly, a good response and support from the public will offer the SMEs the chance 
to measure the potentials and success of their business models (Ramsey 2012). In addition, they could also source for funding from venture capitalists and business angels.

\subsection{Special Considerations in Agency Theory}

More broadly, after reviewing and interpreting literature the study adopts the Agency theory because the theory works in a similar sense as asymmetric information and it is applicable in the field of crowdfunding (Mollick 2014). The agency theory works under the assumption that the principal and the agent has divergent interest and the appropriate way for the principal to limit this is to provide a better incentive packages for the agent(Chod and Lyandres 2018). In addition, the principal needs to pay the agent to spend resource to make sure certain decisions the agent takes will not harm the interest of the principal (Martin, Wiseman, and Gomez-Mejia 2019). The stakeholders, which includes employees, communities, the public, customers, suppliers, and creditors, have some form of legitimate claim or interest in the business(Martin, Wiseman, and Gomez-Mejia 2019). It must be stated that the claim or the interest of the stakeholders is based on the size or proportion of stake in the business (CuervoCazurra, Mudambi, and Pedersen, 2019). In broader terms, stakeholders like the banks who provide loans to the business will want interest payment on their loans. Employees wants better salaries, job security and good working conditions. Suppliers will want long-term contracts and stable contracts and prompt payments for their supplies (Chod and Lyandres 2018). Investors who provide the resources in the form of capital to the business also want returns on their capital. Customers will want value for money(Martin, Wiseman, and Gomez-Mejia 2019). The state and the community that provide the business with infrastructure and location will expect corporate social responsibilities, tax payment and the protection of the environment(Martin, Wiseman, and Gomez-Mejia 2019). As illustrated in Figure 2.

The stakeholder relationship, gives the managers certain privileges because they play unique roles. Unlike the other stakeholders, only the managers can sign contract with the other stakeholders. They control the business and take decisions on resources allocation and strategies on the operations of the business (Hill, C. W., \& Jones 1992). It must be stated clear, the theory which is based on principal - agent model gives the principal the power to designs the contract which must be signed by the managers (Martin, Wiseman, and Gomez-Mejia 2019). The contract spells the level of interaction between the managers and the principal and the remuneration that will be given to the managers. The managers therefore perform services on the principal's behalf of (Pouryousefi and Frooman 2019). This notwithstanding based on the definition of the theory not all the stakeholders can be classified as principals. For instances not all the customers get involve in hiring the agent. The same argument can be advanced for the creditors and suppliers. 


\subsection{Linking agency theory to Crowdfunding}

Empirical investigations conducted on the stakeholder relationships identified platforms, start-ups and backers as the main stakeholders of crowdfunding (Beugre 2014). Accordingly, the linkages between these stakeholders form the basic structure of crowdfunding process. The start-ups often make open calls for funding and promise financial returns or rewards for backers (Moon and Hwang 2018). The backers are the members of crowdfunding society who pledge their financial resources to the project, (Chod and Lyandres 2018). Crowdfunding platforms, which serve as intermediaries, connect the backers to entrepreneurs. The platforms create a conducive atmosphere for the startups to present their ideas to the public and ask for funding (Dushnitsky and Fitza 2018). The start-ups offer the backers something in return for their money. For example, a small gift for a reward and equity that offers a percentage of the start-up. Again, when a project is successfully crowdfunded, the start-ups usually pay a percentage of the amount raise as a fee to the platforms. The fee varies from platform to platform. Kickstarter for instance charges a fee of 5\% and Indiegogo charges 4\% (Valan and Jegelevi 2014).

The relationship between the agency theory stakeholders and crowdfunding can be classified into contextual and organizational (Valančienè and Jegelevičiūte 2014). Within the contextual stakeholders is the state and the society. The state enact laws and pass regulations, which controls the activities of the crowdfunding platforms, peer-to-peer crowdfunding and equity crowdfunding to protect investors. Usually, the state also expects crowdfunding companies to contribute to job creation (employees are hired by crowdfunding platforms and companies), encourage innovation and enhance economic growth and recovery, (Beugre 2014). In addition, the organizational stakes holders such as

banks and shareholders create revenue and increase sales because of marketing strategies. The figure below demonstrate the interaction between the agent, the principal and third parties. 


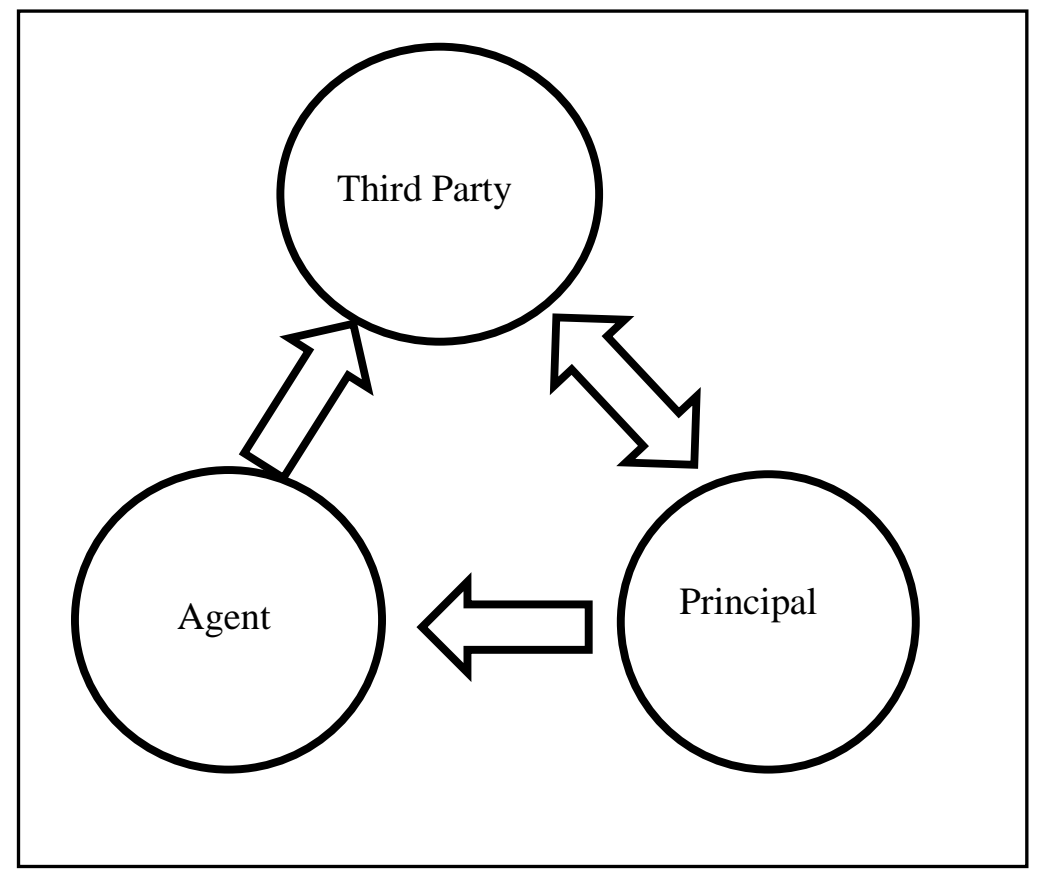

Figure 2 Agency Theory Model

Source: Ross et al (2006)

\subsection{Challenges of Agency Theory}

An extant review of literature on agency theory indicates a dissimilarity in the goal of the agent and the principal regarding the operation of the business(Pouryousefi and Frooman 2019). This usually creates a conflict of interested situation between the two parties. The argument is that the performance of the agent may not match that of the principle and this could create disaffection between the two stakeholders.

In addition, it has been argued that due to separation of ownership and management (Goebel 2019), the principal often have superior information, which is denied the agent and thereby resulting in information asymmetry. This may be private information, which regards the running of the business, investments, performance and abilities of the agent(Valančiene and Jegelevičiūte 2014). The managers therefore take advantage by exploiting the situation to their benefit resulting in agency cost (Cuervo-Cazurra, Mudambi, and Pedersen 2019; Company, Jensen, and Meckling 1976; Auronen 2003; Martin, Wiseman, and Gomez-Mejia 2019; Hill, C. W., \& Jones 1992) 


\section{Conclusion}

We evaluate and discuss how companies will prioritize their sources of financing in terms of the source that will inure to their benefit. Pecking Order Theory therefore figures prominently in the funding streams of startup businesses. We also consider how the dissimilarities in the goals of the agent and the principal in the agency theory affects the operations of a business. In addition, in terms of prioritization companies will prefer their own internal funds for their operations rather than external sources. Within this paper, we therefore make the following theoretical contributions; first, we advanced the view that theoretical aspects of crowdfunding are relevant in enhancing the study if crowdfunding as a field of study. We therefore propose a research agenda that will enhance the practical and theoretical concepts of the financing gaps facing start-ups. Second, our paper advanced the view that there is a need for a clear-cut alternate funding for start-ups to address these gaps. Largely, based on evidence emerging from the literature, we propose that start-ups should rather adopt crowdfunding as an alternative finance in order to avoid their current disjointed funding streams. 


\section{References}

Agrawal, Ajay, Christian Catalini, and Avi Goldfarb. 2014. Some Simple Economics of Crowdfunding. Innovation Policy and the Economy. Vol. 14. https://doi.org/10.1086/674021.

. 2015. "Crowdfunding: Geography, Social Networks, and the Timing of Investment." Journal of Economics \& Management Strategy 24 (2, SI): 253-74. https://doi.org/10.1111/jems.12093.

Agrawal, Ajay K, Christian Catalini, Avi Goldfarb, Pierre Azoulay, Iain Cockburn, Gary Dushnitsky, Richard Florida, et al. 2011. "THE GEOGRAPHY OF CROWDFUNDING We Thank The Geography of Crowdfunding." https://www.nber.org/papers/w16820\%0Awww.netinst.org.

Ahlers, Gerrit K.C., Douglas Cumming, Christina Günther, and Denis Schweizer. 2015. "Signaling in Equity Crowdfunding." Entrepreneurship: Theory and Practice 39 (4): 955-80. https://doi.org/10.1111/etap.12157.

Aryeetey, Ernest. 2005. "Informal Finance for Private Sector Development in Sub-Saharan Africa." Journal of Microfinance / ESR Review 7 (1): 3.

Auronen, Lauri. 2003. “<Auronen 2003.Pdf>," 1-35.

Bellavitis, Cristiano, Igor Filatotchev, Dzidziso Samuel Kamuriwo, and Tom Vanacker. 2017. "Entrepreneurial Finance: New Frontiers of Research and Practice: Editorial for the Special Issue Embracing Entrepreneurial Funding Innovations." Venture Capital 19 (1-2): 1-16. https:/ / doi.org/10.1080/13691066.2016.1259733.

Belleflamme, Paul, Thomas Lambert, and Armin Schwienbacher. 2014. "Crowdfunding: Tapping the Right Crowd." Journal of Business Venturing 29 (5): 585-609. https://doi.org/10.1016/j.jbusvent.2013.07.003.

Berndt, Adele, and Marvin Mbassana. 2016. "East Africa Collaborative Ph . D . Program in Economics and Management East Africa Research Papers in Business, Entrepreneurship and Management Crowdfunding : The Beliefs of Rwandan Entrepreneurs East Africa Research Papers in Business ,.”

Beugre, C. D. 2014. “The Legitimacy of Crowdfunding: An Institutional Theory Perspective." Academy of Management Proceedings 2014 (1): 10611-10611. https://doi.org/10.5465/ambpp.2014.10611abstract.

Bhama, Vandana, Pramod Kumar Jain, and Surendra Singh Yadav. 2019. "Pecking Order Test at Varying Debt Levels: A Comparative Study of Indian and Chinese Firms." Journal of Emerging Market Finance 18 (2): 237-61. https://doi.org/10.1177/0972652719846317.

Block, Joern H., Massimo G. Colombo, Douglas J. Cumming, and Silvio Vismara. 2018. "New Players in Entrepreneurial Finance and Why They Are There." Small Business Economics 50 (2): 239-50. https://doi.org/10.1007/s11187-016-9826-6.

Cambridge centre for Alternative Finance. 2017. “Crowdfunding in East Africa: Regulation and Policy for Market 
Development Reducing Poverty Through Financial Sector Development.” Report, no. January. https://www.jbs.cam.ac.uk/fileadmin/user_upload/research/centres/alternative-finance/downloads/2017-05eastafrica-crowdfunding-report.pdf.

Chod, Jiri, and Evgeny Lyandres. 2018. "A Theory of ICOs: Diversification, Agency, and Information Asymmetry." SSRN Electronic Journal. https://doi.org/10.2139/ssrn.3159528.

Company, Publishing, C Jensen, and H Meckling. 1976. "Theory of the Firm : Managerial Behavior, Agency Costs and Ownership Structure I . Introduction and Summary in This Paper WC Draw on Recent Progress in the Theory of (1) Property Rights, Firm . In Addition to Tying Together Elements of the Theory of E” 3: 305-60.

Cosh, Andy, Douglas Cumming, and Alan Hughes. 2009. “Outside Enterpreneurial Capital *” 119 (1970): 1494-1533. https://doi.org/10.1111/j.1468-0297.2009.02270.x.

Cox, Joe, and Thang Nguyen. 2018. "Does the Crowd Mean Business? An Analysis of Rewards-Based Crowdfunding as a Source of Finance for Start-Ups and Small Businesses." Journal of Small Business and Enterprise Development 25 (1): 147-62. https://doi.org/10.1108/JSBED-05-2017-0165.

Crosetto, Paolo, and Tobias Regner. 2018. "It's Never Too Late: Funding Dynamics and Self Pledges in Reward-Based Crowdfunding.” Research Policy 47 (8): 1463-77. https://doi.org/10.1016/j.respol.2018.04.020.

Cuervo-Cazurra, Alvaro, Ram Mudambi, and Torben Pedersen. 2019. "Subsidiary Power: Loaned or Owned? The Lenses of Agency Theory and Resource Dependence Theory." Global Strategy Journal, no. October: 1-11. https://doi.org/10.1002/gsj.1362.

Cumming, Douglas J., Gaël Leboeuf, and Armin Schwienbacher. 2019. “Crowdfunding Models: Keep-It-All vs. All-OrNothing.” Financial Management, 1-41. https://doi.org/10.1111/fima.12262.

Dieter, Hans. 2001. "Www.Econstor.Eu.”

Dorfleitner, Gregor, Lars Hornuf, and Martina Weber. 2018. "Dynamics of Investor Communication in Equity Crowdfunding." Electronic Markets 28 (4): 523-40. https://doi.org/10.1007/s12525-018-0294-5.

Dushnitsky, Gary, and Markus A. Fitza. 2018. "Are We Missing the Platforms for the Crowd? Comparing Investment Drivers across Multiple Crowdfunding Platforms.” Journal of Business Venturing Insights 10 (October): 1-10. https://doi.org/10.1016/j.jbvi.2018.e00100.

Estrin, Saul, Daniel Gozman, and Susanna Khavul. 2018. "The Evolution and Adoption of Equity Crowdfunding: Entrepreneur and Investor Entry into a New Market.” Small Business Economics 51 (2): 425-39. https://doi.org/10.1007/s11187-018-0009-5.

Goebel, Viktoria. 2019. "Drivers for Voluntary Intellectual Capital Reporting Based on Agency Theory." Journal of Intellectual Capital 20 (2): 264-81. https://doi.org/10.1108/JIC-01-2018-0019. 
Hervé, Fabrice, and Armin Schwienbacher. 2018. "Crowdfunding and Innovation.” Journal of Economic Surveys 32 (5): 1514-30. https://doi.org/10.1111/joes.12274.

Hill, C. W., \& Jones, T. M. 1992. “Stakeholder-Agency Theory Charles.” Journal of Management Studies 29 (2): 131-54.

Hiller, Alexander. 2017. "An Empirical Analysis of Crowdfunding in Sub-Saharan Africa,” 209.

Howe, Jeff. 2006. “The Rise of Crowdsourcing.” Wired Magazine 14 (06): 1-5. https://doi.org/10.1086/599595.

InfoDev. 2015. "Crowdfunding in Emerging Markets: Lessons from East African Startups B Crowdfunding in Emerging Markets: Lessons from East African Startups."

Jarallah, Shaif, Ali Salman Saleh, and Ruhul Salim. 2019. "Examining Pecking Order versus Trade-off Theories of Capital Structure: New Evidence from Japanese Firms.” International Journal of Finance and Economics 24 (1): $204-11$. https://doi.org/10.1002/ijfe.1657.

Kaartemo, Valtteri. 2017. "The Elements of a Successful Crowdfunding Campaign: A Systematic Literature Review of Crowdfunding Performance." International Review of Entrepreneurship 15 (3).

Kuppuswamy, Venkat, and Barry L. Bayus. 2017. "Does My Contribution to Your Crowdfunding Project Matter?” Journal of Business Venturing 32 (1): 72-89. https://doi.org/10.1016/j.jbusvent.2016.10.004.

Kuppuswamy, Venkat, and Barry L Bayus. 2013. "Crowdfunding Creative Ideas: The Dynamics of Projects Backers in Kickstarter. SSRN Working Paper Series."

Landström, Hans, Annaleena Parhankangas, Colin Mason, and Gary Dushnitsky. 2019. "The Role of Crowdfunding in Entrepreneurial Finance." Handbook of Research on Crowdfunding 13 (2): 46-92. https://doi.org/10.4337/9781788117210.00008.

Martin, Geoffrey P., Robert M. Wiseman, and Luis R. Gomez-Mejia. 2019. “The Interactive Effect of Monitoring and Incentive Alignment on Agency Costs." Journal of Management 45 (2): 701-27. https://doi.org/10.1177/0149206316678453.

Martínez-Climent, Carla, Ana Zorio-Grima, and Domingo Ribeiro-Soriano. 2018. "Financial Return Crowdfunding: Literature Review and Bibliometric Analysis.” International Entrepreneurship and Management Journal 14 (3): $527-53$. https://doi.org/10.1007/s11365-018-0511-x.

Moedl, Michael M. 2019. "Entrepreneurial Equity Pecking Order."

Mollick, Ethan. 2014. “The Dynamics of Crowdfunding: An Exploratory Study.” Journal of Business Venturing 29 (1): 1-16. https://doi.org/10.1016/j.jbusvent.2013.06.005. 
Moon, Younghwan, and Junseok Hwang. 2018. "Crowdfunding as an Alternative Means for Funding Sustainable Appropriate Technology: Acceptance Determinants of Backers.” Sustainability (Switzerland) 10 (5): 1-17. https://doi.org/10.3390/su10051456.

Platforms, Africa-based Crowdfunding. n.d. "Fundraising Goes Digital in Africa : The Emergence Of."

Pouryousefi, Sareh, and Jeff Frooman. 2019. “The Consumer Scam: An Agency-Theoretic Approach.” Journal of Business Etbics 154 (1). https://doi.org/10.1007/s10551-017-3466-x.

Sahm, Marco, Paul Belleflamme, Thomas Lambert, and Armin Schwienbacher. 2014. "Corrigendum to 'Crowdfunding: Tapping the Right Crowd."' Journal of Business Venturing 29 (5): 610-11. https://doi.org/10.1016/j.jbusvent.2014.06.001.

Valan, Loreta, and Sima Jegelevi. 2014. "Crowdfunding for Creating Value : Stakeholder Approach" 156 (April): 599 604. https://doi.org/10.1016/j.sbspro.2014.11.248.

Valanciene, Loreta, and Sima Jegeleviciute. 2013. "VALUATION OF CROWDFUNDING :” 18 (1): 39-48.

Valančienè, Loreta, and Sima Jegelevičiùtè. 2014. "Crowdfunding for Creating Value: Stakeholder Approach.” Procedia Social and Behavioral Sciences 156 (April): 599-604. https://doi.org/10.1016/j.sbspro.2014.11.248.

Vanacker, Tom R, and Æ Sophie Manigart. 2010. "Pecking Order and Debt Capacity Considerations for High-Growth Companies Seeking Financing,” 53-69. https://doi.org/10.1007/s11187-008-9150-x.

Vershinina, Natalia, Kassa Woldesenbet Beta, and William Murithi. 2018. "How Does National Culture Enable or Constrain Entrepreneurship? Exploring the Role of Harambee in Kenya." Journal of Small Business and Enterprise Development 25 (4): 687-704. https://doi.org/10.1108/JSBED-03-2017-0143.

Vismara, Silvio. 2016. "Equity Retention and Social Network Theory in Equity Crowdfunding." Small Business Economics 46 (4): 579-90. https://doi.org/10.1007/s11187-016-9710-4.

2018. "Information Cascades among Investors in Equity Crowdfunding." Entrepreneurship: Theory and Practice 42 (3): 467-97. https://doi.org/10.1111/etap.12261.

Walthoff-Borm, Xavier, Armin Schwienbacher, and Tom Vanacker. 2018. "Equity Crowdfunding: First Resort or Last Resort?” Journal of Business Venturing 33 (4): 513-33. https://doi.org/10.1016/j.jbusvent.2018.04.001. 